\title{
Editorial
}

\section{Role of Biomarkers for the Screening of Preeclampsia, are we there yet?}

\section{Erry G Dachlan}

Preeclampsia is a global maternal health burden due to its high maternal mortality and morbidity, especially in developing countries, which appears in Indonesia. ${ }^{1}$ Two hundred and sixty-threemillion people occupying a large area of Indonesia gave rise the problem of the high maternal mortality rate of 305/100,000 deliveries where preeclampsia (PE) and eclampsia (E) stand out as a massive health care problem in Indonesia with some teaching hospital rates approximately ranged 22-25\%. Although the precise pathophysiology of PE remains obscure, ${ }^{3,4}$ It has beenstrongly suggested that placental dysfunction with released factors containing excessive oxidative molecules, trophoblast debris and proinflammatory cytokine into the maternal circulation, inducing widespread endothelial dysfunction that heralds the classic manifestations of the disease.

It has been widely accepted that serving with PE prevention much better than treatment, so early detection and risk identification from those related woman group might have been mostly considering effort into health strategic campaign. With this regard clearly biomarker assesment has posed its position to be required interestingly. The ability to predict PE would be a major advance in maternalfetal medicine, it is known well that several proposed biomarkers comprising angiogenic markers (sFli-1,VEGF,PIGF and sEng) in maternal circulation precede the clinical onset of PE by severalweeks to months, Placental Protein-13 is a member of the galectin family, predominantly expressed by the syncytiotrophoblasts, that is involved in normal implantation and placental vascular development, Pregnancy-Associated Plasma Protein A is a peptidase produced by syncitiotrophoblast with hydrolytic activity for insulin-like growth factor- binding proteins, and Free Fetal Nucleic-Acids circulate in the maternal blood ${ }^{5-8}$.

What would be needed largely nowadays for tropical, coastal and developing state not sophisticated and expensively aboved sort of methods but much more likely such a test of affordable, good accuracy and accountability. However, it could be not other than combined test comprising simply found history taking of risk factors (i.e. elderly primigravida less than 35 years old, genetic, obesity, twin etc.), BMI, MAP and uterine artery Doppler velocimetry (UADV). Although it was never reached the best prediction result, only a little bit lower compared to those what Espinoza et al said in their study as the prediction sensitivities of maternal plasma PIGF concentration, abnormal UADV, and the combination of these test were $61.35 \%$ and $27 \%$, respectively. His research group conducted a prospective study of 3296 women to determine the role of UADV, maternal plasma PIGF among others, where sample collection and UADV were performed between 22 and 26 weeks. ${ }^{6,7}$ 


\section{REFERNCES}

1. Ilham M, Aldika Akbar M, Bachnas M, Cornelius Mose J, Dachlan G, Ernawati E, et al. The massive problem of preeclampsia in indonesia: In need of a redesigned national health care system. Pregnancy Hypertens An Int J Women's Cardiovasc Heal [Internet]. 2018;13:S16-s49. Available from: https://doi.org/10.1016/j.preghy.2018.08.051

2. Ardian M, Adityawarman, Hermanto, Sulistyono, Dachlan EG. The characteristic of Indonesia's pre-eclampsia: From obstetric intensive care with a ventilator until epidemiologic and its molecular biology profile of pulmonary edema in severe pre-eclampsia. Pregnancy Hypertens An Int J Women's Cardiovasc Heal [Internet]. 2014;4(3):245. Available from: http://dx.doi.org/10.1016/j.preghy.2014.04.018

3. WHO. WHO recommendations for prevention and treatment of pre-eclampsia and eclampsia [Internet]. Vol. 18, Postgraduate medicine. 1955. 165-173 p. Available from: http://apps.who.int/iris/bitstream/handle/10665/44703/9 789241548335_eng.pdf?sequence $=1$

4. Park HJ, Shim SS, Cha DH. Combined screening for early detection of pre-eclampsia. Int J Mol Sci. 2015;16(8):1795274.

5. Cerdeira A, Karumanchi S. Biomarkers in preeclampsia. In: Edelstein CL, editor. Biomarkers in Kidney Disease [Internet]. 2nd ed. Boston: Elsevier Inc; 2010. p. 385-426. Available from: http://dx.doi.org/10.1016/B978-0-12-8030141.00014-5

6. Salan YDC. Biomarker Terkini Dalam Usaha Memprediksi Preeklampsia. Berk Kedokt. 2018;13(1):119.

7. Nisa H, Lokajaya T, Sinuraya RK, Puri TNS. PIGF/sFlt 1 as Early Detection Biomarker for Preeclampsia. Indones J Clin Pharm [Internet]. 2018;6(2):123-34. Available from: http://ijcp.or.id

8. Syaharutsa, Danny Maesadatu; Purwosunu Y. A Scoring System for Preeclampsia Screening Based on Maternal and Biophysical Factors: Result from a 3-Month Cohort Study in Jakarta, Indonesia. Adv Sci Lett. 2018;24(9):63616365(5). 